\title{
Interkulturális kompetenciák az egészségügyi ellátásban
}

\author{
Marek Erika dr. ${ }^{1}$. Németh Tímea dr. ${ }^{2}$ \\ ${ }^{1}$ Pécsi Tudományegyetem, Általános Orvostudományi Kar, Múveleti Medicina Tanszék, Pécs \\ ${ }^{2}$ Pécsi Tudományegyetem, Általános Orvostudományi Kar, Egészségügyi Nyelvi és Kommunikációs Intézet, Pécs
}

\begin{abstract}
A 2013-as évet követő, fokozódó nemzetközi migrációs nyomás váratlan kihívások elé állította az európai uniós tranzit- és célországok egészségügyi ellátórendszereit és szakembereit. Európa-szerte is egyre inkább előtérbe került az olyan, ún. 'kulturálisan kompetens' egészségügyi ellátórendszerek kialakításának fontossága, amelyek képesek alkalmazkodni és megfelelő választ adni a változó összetételű populációk szükségleteire, valamint figyelembe veszik a kulturális, vallási és nyelvi sokszínúséget. Ma már köztudott, hogy az egészségi állapotban mutatkozó egyenlőtlenségek hátterében főként társadalmi-gazdasági tényezők állnak, és hogy ezek az egyenlőtlenségek egyes etnikai és kulturális kisebbségek körében különösen nyilvánvalóak. Esetükben ehhez hozzáadódik, hogy gyakran még az egészségügyi ellátáshoz való hozzáférés is komoly akadályokba ütközik, beleértve a nyelvi és kulturális különbségekből eredő akadályokat, amelyek elsődlegesen az ellátórendszer és a beteg közötti kommunikáció és egyéb interakciók során manifesztálódnak. A kommunikációs nehézségek és félreértések az ellátók körében frusztrációhoz és elöítéletekhez, a betegek részéről pedig az orvossal való együttmúködés hiányához is vezethetnek, így hosszú távon hozzájárulhatnak a betegek rosszabb egészségi mutatóihoz. Mindezek alapján nyilvánvaló, hogy a lehető legjobb minőségű egészségügyi ellátás biztosítása érdekében a többségi társadalomtól eltérő nyelvű, kultúrájú, vallású migráns, etnikai vagy más kisebbségi populációk ellátása során egyre nagyobb figyelmet kell fordítani a különbözőségekből fakadó nehézségek leküzdésére, és ennek egyik fontos lépése az interkulturális kompetenciák fejlesztése az egészségügyi ellátórendszerben. Közleményünkben az interkulturális kompetencia fogalmát, tartalmát és fejlesztési lehetőségeit járjuk körül klinikai és egészségügyi környezetben.
\end{abstract}

Orv Hetil. 2020; 161(32): 1322-1330.

Kulcsszavak: egészségegyenlőtlenség, interkulturális kompetencia, orvosképzés, ellátás minősége, migráció, migránsok

\section{Intercultural competence in healthcare}

International migration is a current and growing phenomenon, which has become an increasingly critical issue in Europe since 2013 and this has posed new challenges to the healthcare systems of the European Union (EU). The need for 'culturally competent' healthcare systems that can adapt and respond to the needs of a changing population while taking into account cultural, religious, linguistic and gender diversity, has become more and more an agenda across Europe. Nowadays, it is widely accepted that inequalities in health conditions are mainly due to socio-economic factors, and disparities are particularly evident among certain ethnic and cultural minority groups. Additionally, minorities often face difficulties during their attempts in accessing healthcare, including linguistic and cultural barriers. These barriers are primarily manifested in communication and other interactions between the patient and the healthcare provider. Communication difficulties and misunderstandings may lead to frustration and prejudice among caregivers and also to a lack of cooperation from patients, and consequently, may contribute to poorer health outcomes. Therefore, in order to ensure the highest quality of care for migrants, ethnic or other minority populations in our increasingly diverse societies, it is of crucial importance to overcome the difficulties arising from linguistic, cultural and religious differences. To achieve these goals, an important step is the development of intercultural competences within the healthcare system. Our paper discusses the concept, content and opportunities for the development of intercultural competence in clinical and healthcare settings.

Keywords: health inequalities, intercultural competence, medical education, quality of care, migrants, migration

Marek E, Németh T. [Intercultural competence in healthcare]. Orv Hetil. 2020; 161(32): 1322-1330.

(Beérkezett: 2020. április 7.; elfogadva: 2020. április 22.) 


\section{Rövidítések}

ÁOK = Általános Orvostudományi Kar; EU = (European Union) Európai Unió; PTE = Pécsi Tudományegyetem; SDH = (social determinants of health) az egészség társadalmi meghatározói; UNESCO = (United Nations Educational, Scientific and Cultural Organization) az Egyesült Nemzetek Nevelésügyi, Tudományos és Kulturális Szervezete; WHO = (World Health Organization) Egészségügyi Világszervezet

2013 első félévétől kezdődően korábban soha nem látott mértékủ menekültáradat érte el Európát, amely váratlan kihívások elé állította az európai uniós tranzit- és célországok egészségügyi ellátórendszereit és szakembereit. Az új kihívások kezelésére 2015 őszén az Egészségügyi Világszervezet (World Health Organization, WHO) „Menekültek és migránsok egészsége” címmel csúcstalálkozót szervezett (High-level Meeting on Refugee and Migrant Health), melynek záródokumentuma felhívja a tagországok figyelmét az ún. „migránsérzékeny" egészségügyi ellátórendszerek kialakításának fontosságára, amelyek képesek alkalmazkodni és megfelelő választ adni a folytonosan változó összetételû́ bevándorló- és más migránspopulációk ${ }^{1}$ szükségleteire, valamint figyelembe veszi a kulturális, vallási és nyelvi sokszínúséget [1]. Az utóbbi évek nemzetközi tudományos szakirodalmában is egyre több közlemény hívja fel a figyelmet az ún. 'interkulturális kompetenciák' szerepére a többségi társadalomtól eltérő kulturális háttérrel rendelkező populációk egészségügyi ellátásában, beleértve az egyes hazai etnikai, vallási vagy más kisebbségek ellátását is, valamint hangsúlyozza az egészségügyben dolgozók ilyen irányú képzésének szükségességét [2-5]. Az interkulturális kompetenciákra az egészségügyben azonban nemcsak a menekültek és más migránscsoportok vagy kisebbségek ellátásakor van szükség, hanem a hazai felsőoktatásban tanuló külföldi orvostanhallgatók oktatása, illetve nemzetközi orvosés kutatócsoportokban való hatékony együttmúködések során egyaránt.

Pontosan mit is jelent az 'interkulturális kompetencia' fogalma klinikai, egészségügyi környezetben, van-e jelentősége a betegellátásban, hatással lehet-e, és ha igen, milyen hatással lehet az ellátás minőségére, valamint az egyének és közösségek egészségi állapotára? Többek között ezekre a kérdésekre kívánunk közleményünkben reflektálni.

\footnotetext{
' A cikkben migráns gyújtőfogalom alatt értjük a hazánkban jogszerútlenül tartózkodó irreguláris migránsokat, továbbá a menedékkéróket és elismert státuszszal rendelkezőket (menedékes, oltalmazott, menekült vagy befogadott), valamint a hosszabb-rövidebb ideig Magyarországon élö, tartózkodási és/vagy letelepedési engedéllyel rendelkező bevándorlókat és más külföldi állampolgárokat (diplomaták, külföldi vendéghallgatók és munkavállalók stb.). További információ: www.iom.int/key-migration-terms
}

\section{Az 'interkulturális kompetencia' definíciójának fejlődése}

\section{A kultúra és az egészség kapcsolata}

Az Egyesült Nemzetek Nevelésügyi, Tudományos és Kulturális Szervezete (UNESCO) 2001-ben fogadta el egyetemes nyilatkozatát a kulturális sokszínúségről, melyben a kultúra fogalmát az alábbiak szerint definiálja: „egy társadalom vagy társadalmi csoport sajátos lelki, tárgyi, szellemi és érzelmi jegyeinek együttese, mely magában foglalja a müvészeteken és az irodalmon kivïl az életstílust, az együttélés módjait, az értékrendszert, a hagyományokat és a hiedelmeket” [6]. Mivel az egyes társadalmak felépítése rendkívül komplex, a populáció számos különböző kultúrából és szubkultúrából épül fel, amelyek egymás között elemeikben átmenetet képezhetnek, ráadásul az összetétele folyamatosan változik, ezért soha nem tekinthetô homogén halmaznak, így a kultúra fogalmát is érdemes komplex, folyamatosan változó és alkalmazkodó fogalomként kezelni. Számos modell ismert, melyek a kultúra különböző rétegeit, megnyilvánulási szintjeit különítik el, például Hofstede hagymamodellje vagy a közismert ún. jéghegymodell $[7,8]$. Ezek mindegyike megkülönbözteti a kultúrának a külső szemlélő számára is látható elemeit (például nyelv, öltözködés, szokások) a szemmel nem látható, sokkal mélyebben gyökerező normáktól, hit- és értékrendszertôl.

Köztudott, hogy a kulturális háttér az élet számos területére hatással van, beleértve a nyelvet, a vallást, a világlátást, a tér és idő értelmezését, a családszerkezetet, a hiedelmeket, a rituálékat, a diétát, a viselkedést, a betegséghez és a fájdalomhoz való hozzáállást stb. Mindezek pedig közvetve és akár közvetlenül is hatással lehetnek az egyén és a közösségek egészségére, illetve az egészségügyi ellátórendszerrel való kapcsolatukra. A kultúrkör, amelybe születtünk és amelyben élünk, nem tisztán, önmagában határozza meg az egészséggel kapcsolatos hiedelmeinket és egészségmagatartásunkat, hanem számos más tényezővel együttesen. Ilyen tényező́k lehetnek egyes egyéni, személyes tényezők (például nem, kor, személyes tapasztalatok, fizikai és érzelmi állapot), az iskolázottság (beleértve egy adott vallási szubkultúrába való 'beiskolázottságot' is), illetve egyes társadalmi-gazdasági tényezók, melyeknek része a szociális támogató környezet vagy annak hiánya és az esetleges diszkrimináció is [9]. Viselkedésünket egy-egy szituációban különböző mértékben befolyásolja kultúránk és a többi tényező: vannak helyzetek, melyekben reakcióinkat elsődlegesen a sokkal mélyebben gyökerező kultúránk határozza meg, semmint az iskolázottságunk, a pillanatnyi érzelmi állapotunk vagy egyéb külső vagy 'szerzett' tényező [9]. Hofstede holland szociálpszichológus az 1970-es évek végén publikálta modelljét a kultúra egyes dimenzióiról, és munkája nagymértékben hozzájárult a kultúrák közötti különbségek megértéséhez [10]. Néhány példa szemléltetésképpen egészségügyi megközelítésből: pél- 
dául az olyan kultúrákban, ahol jellemzően nagy a 'hatalmi távolság' ('power distance'), nagyobb az orvos (mint hatalom) tekintélye és az orvossal szembeni elvárások is (például Irán, Törökország), mint az olyan kultúrákban, ahol a hatalmi távolság kisebb, és az orvos inkább mint egyenrangú fél, vagy 'barát' megbeszéli a beteggel a lehetséges kezelési opciókat, és szinte közösen hoznak döntéseket (például Norvégia). Egy 'kollektivista' kultúrában egészen más a család szerepe a beteg ápolásában és támogatásában (például a nagy rokonság egyszerre látogatja meg a beteget, mint a roma etnikai kisebbség vagy egyes muszlim vallású csoportok esetében), mint az ún. 'individualista' társadalmakban (például Hollandia).

\section{Az 'interkulturális kompetencia' definíciója}

A fokozódó társadalmi mobilitással és a társadalmak etnikai és kulturális szempontból egyre sokszínúbbé válásával mindinkább felmerült az igény az orvos-beteg kommunikáció hatékonyabbá tételére és ezáltal az ellátás minőségének javítására. A 'kulturális kompetencia' koncepciója megjelent és gyorsan népszerúvé vált, elsőként - nem meglepő módon - az amerikai egészségpolitikai tervezésben és egészségügyi ellátórendszerben. Maga a 'kompetencia' kifejezés latin eredetû szó (competentia), etimológiai gyökere a 'competo', azaz 'egybeesik valamivel, illő, elegendő valamihez', és a szó számos értelmezéséből a 'képes valamire' jelentés áll a legközelebb a mai nyelvhasználathoz [11]. A kompetencia fogalmát Chomsky amerikai nyelvész alkotta meg és vezette be a köztudatba az 1950-es évek végén, majd a nyelvészetből honosodott meg fokozatosan a humán és társadalomtudományokban, és megszületett a 'kommunikatív kompetencia' fogalmi kerete, amely a beszélők közötti diskurzusokra fókuszált [11]. A szociális, majd az egészségügyi területeken a hetvenes-nyolcvanas években kezdett érlelődni a 'kulturális kompetencia' fogalma, párhuzamosan az emberjogi mozgalmak kibontakozásával, valamint olyan orvosi, antropológiai kutatásokkal, melyek sajátos, kultúraspecifikus szindrómákat és ún. „népbetegségeket” tártak fel, amelyek kizárólag egy-egy helyi kultúra határain belül találhatók, és amelyekról a nyugati orvostudománynak azt megelőzően nem sok fogalma volt $[11,12]$.

A 'kulturális kompetencia' és 'interkulturális kompetencia' fogalmakat mind a hazai, mind a nemzetközi szakirodalom szinte egyenértékü, egymással felcserélhető fogalmakként használja, teoretikusan azonban az 'interkulturális', vagy magyarosabban 'kultúrközi’ kifejezés kifejezőbben utal a kompetenciáknak az egymástól eltérő kultúrák közötti mibenlétére. Elterjedt, de viszonylag ritkábban használt, rokon értelmü kifejezés még a 'multikulturális' kompetencia, illetve a 'transznacionális' kompetencia is, sőt szórványosan még az amerikai irodalomból átvett 'krosszkulturális' kifejezés is megjelenik [13]. Ugyanakkor a következő kifejezések használata mögött már koncepcióbeli különbségek is állnak: például 'kulturális sokszínűség' (cultural diversity), 'kulturális érzékenység' (cultural sensitivity), valamint 'sokszínúségérzékenység' (diversity sensitivity). Ez utóbbi kifejezések elsődlegesen a társadalmi, kulturális sokszínűség (diverzitás) szemszögéből közelítik az egészségügyi egyenlőtlenségeket és speciális szükségleteket, és a fó hangsúlyt elsősorban a sokszínúségre helyezik, például nemi, kulturális, vallási), és kevésbé a migránsokat, illetve etnikai kisebbségeket érintő, kultúrák közötti kontextusra [14].

Egységes, univerzális 'interkulturális kompetencia' definíció nincs az irodalomban, használata erősen tudományterület- és kontextusfüggő (például egészen más jelentéssel bír az üzleti vagy múszaki tudományos életben, és mással például klinikai környezetben). Talán az egyik leggyakrabban hivatkozott definíció Cross és mtsai általános meghatározása 1989-ből, miszerint „...a kulturális kompetencia olyan egymással összhangban álló attitüdök, magatartásformák és irányelvek összessége, amelyek egy rendszerben, szakmai közegben vagy szakemberek között egymással összekapcsolódnak, és hatékony együttmüködést tesznek lebetöpé számukra kultúrközi helyzetekben” [15]. Betancourt és mtsai 2002-es meghatározása szerint a 'kulturális kompetencia' egészségügyi környezetben „...az ellátórendszer azon képessége, miszerint olyan ellátást tud olyan formában biztositani a különféle (kulturális) értékekkel, meggyözödésekkel és magatartással rendelkezö betegek számára, amely megfelel a betegek szociális, kulturális és nyelvi szükségleteinek” [16].

Végül fontos megemlíteni, hogy bár az 'interkulturális kompetencia' fogalma történetileg nyelvészeti és kommunikációs eredetű, és funkcionalitásában szorosan öszszefügg az 'interkulturális kommunikációval', a tartalmuk nem ekvivalens, ezért a két fogalom egymással nem keverendő: az interkulturális kommunikációs képesség a szerzők értelmezése szerint - az interkulturális kompetenciáknak egy fontos részét képezi, míg az 'interkulturális kompetencia' attól sokkal tágabb, több dimenziót magában foglaló koncepció. A kommunikációtudomány egyes értelmezései szerint viszont éppen fordított a helyzet: az 'interkulturális kompetenciák' és a 'kommunikatív kompetenciák' képezik részét a tágabb, ún. 'interkulturális kommunikatív kompetencia' halmaznak $[17,18]$.

\section{Az interkulturális kompetencia összetevői}

Ahogy nincs univerzális 'interkulturális kompetencia' definíció, hasonlóképpen számos különböző 'interkulturális kompetencia' modellt találhatunk az irodalomban, eltérő számú és jelentésü komponenssel. Az orvos-, illetve egészségtudományban használt legegyszerúbb modellek a következő három fö komponenst veszik alapul: ismeretek ('knowledge'), készségek ('skills') és attitüdök ('attitudes') [19, 20]. Egyes modellek külön kategóriába sorolják az ún. 'kulturális tudatosságot' ('awareness') (például a saját kulturális identitás ismerete, a saját előítéletek, illetve sztereotípiák felismerése) [21], míg mások ezen szempontokat az 'attitüdök' kategóriáján belül 
értelmezik [19, 22]. Papadopoulos és mtsai 2006-os modellje szerint a kulturális kompetencia mint cél eléréséhez a kulturális tudatosságon és ismereteken kívül elengedhetlen az ún. 'kulturális érzékenység' ('cultural sensitivity'), beleértve a kulturális empátiát, tiszteletet, elfogadást és bizalmat is [21].

A jelen tanulmány szerzői 2016 és 2018 között mérték fel az interkulturális kompetenciát a Pécsi Tudományegyetem Általános Orvostudományi Karának medikus hallgatóinak körében. A kutatáshoz az amerikai Like által szerkesztett, ún. 'klinikai kulturális kompetencia kérdőív' hazai viszonyokra adaptált változatát használták [22]. Ez a kérdő́iv a demográfiai adatokra és az interkulturális képzéseken való részvételre vonatkozó szekciókon túl az interkulturális kompetenciák négy fó dimenzióját vizsgálta: a 'szokásos' ismeretek, készségek és attitűdök hármasán kívül külön szekcióban értékelte az ún. 'szociokulturális felkészültséget igénylő helyzetekben való komfortszintre' vonatkozó kérdéskört.

Az, hogy milyen témák tartozhatnak az interkulturális kompetencia egyes komponensei közé az egészségtudományok területén, szintén nagy változatosságot mutat a nemzetközi szakirodalomban. Ebbe a legjobban az interkulturális kompetencia felmérésére irányuló kutatások eszközeinek (például kérdőívek, interjúvázlatok) vizsgálatával nyerhetünk bepillantást. Mivel a Like által eredetileg orvosokra kifejlesztett és számos más nemzetközi kutatócsoportban alkalmazott és publikált kérdőív állt a leginkább összhangban saját kutatási céljainkkal, és mi is ennek a medikusokra adaptált és kiegészített változatát alkalmaztuk felméréseinkhez, az alábbiakban azt ismertetnénk, hogy ennek a kérdőívnek az egyes szekciói milyen kérdésköröket érintettek [22-25]. Ezek nagyrészt lefedhetik az interkulturális kompetencia egy-egy komponensének tartalmát is klinikai, egészségtudományi területen. A kérdések többségét a válaszadóknak 5 fokozatú Likert-skálán kellett megválaszolniuk, és egyelőre a hazai felmérések első részeredményeiből született közlemény [23].

A kutatás 'ismeretekre' irányuló kérdéscsoportja az alábbi témákra fókuszált (1. táblázat):

A táblázat utolsó öt kérdése nem volt része az eredeti, Like által kifejlesztett kérdőívnek, ezeket saját kutatási céljaink miatt tettük hozzá. Koebn és Swick kanadai kutatók 2006-os tanulmányukban ráirányítják a figyelmet az egészségi állapotban és ellátásban mutatkozó egyenlőtlenségek politikai szintű (szabályozási), szociális, valamint egyéni meghatározottságára is (migrációs okok, háttér, egyéni életesemények, traumák, például kínzás, üldöztetés, diszkrimináció stb.), valamint hangsúlyozzák ezen tartalmak orvosképzésbe integrálását [13]. Ezzel egyetértésben, és tekintettel a 2013-as évet követő fokozott migrációs nyomásra, az orvos- és egészségtudomány területén mi is fontosnak tartjuk az interkulturális ismeretek közé integrálni az esetleges migráció-egészségügyi vonatkozásokat, beleértve a migrációs történetet, hátteret (ún. 'push faktorok'), életeseményeket. Gondoljunk csak a természeti katasztrófáknak, háborúknak vagy kín-
1. táblázat Az interkulturális kompetencia 'ismeretek' komponensének egyes témakörei

Ismeretek önértékelése az alábbi témakörökben

A különböző nemzetiségek, etnikai csoportok demográfiája

A különböző nemzetiségek, etnikai csoportok szociokulturális sajátosságai (például vallás, családszerkezet stb.)

A különböző nemzetiségek, etnikai csoportok által tapasztalt egészségügyi kockázatok

A különböző nemzetiségek, etnikai csoportok által tapasztalt egészségügyi egyenlőtlenségek

Szociokulturális ismeretek az alábbi témakörökben:
a) egészségfejlesztés/betegségmegelőzés
b) reproduktív egészség/várandósság
c) gyerekek egészsége
d) serdülőkorúak egészsége
e) felnőttek egészsége
f) geriátria
g) női egészség

Etnofarmakológia (például a különböző etnikumok eltérő válaszai a terápiára)

Különböző tradicionális gyógyító eljárások (például ayurvédikus medicina, hagyományos kínai orvoslás stb.)

A rasszizmus, diszkrimináció és előítéletek egészségre, egészségügyre gyakorolt hatásai egyes népcsoportoknál a történelem során vagy napjainkban

Országos vagy regionális szakmai irányelvek, ajánlások a kulturális sokszínúség kezelésére az egészségügyi ellátásban

A migránsok egészségügyi ellátáshoz való hozzáférésével kapcsolatos ismeretek (jogosultságok stb.)

A migrációval összefüggő egészségügyi kockázatok

A migrációval kapcsolatos foglalkozás-egészségügyi aspektusok

A roma populáció egészségügyi ellátásával kapcsolatos ismeretek (egészségkép, kulturális különbözőség stb.)

Interkulturális kommunikációval kapcsolatos ismeretek (például alacsony vs. magas kontextusú kommunikáció)

Forrás: saját szerkesztés $R$. C. Like klinikai kulturális kompetencia kérdőíve alapján adaptálva [22]

zásoknak, üldöztetéseknek, az emberkereskedelemnek és embercsempészetnek a fizikai és mentális egészségre gyakorolt hatásaira, melyeket nem lehet figyelmen kívül hagyni az ellátás során. Továbbá egészségtudományi területen szorosan idetartoznak a leggyakoribb eredetországoknak, földrajzi régióknak az epidemiológiai helyzetével kapcsolatos ismeretek is: például egyes, a fogadó országokban már ritka vagy eradikáltnak tekinthető betegségek gyakoribb előfordulása a küldő országokban, a védőoltásokkal való lefedettség, a közegészségügyi ellátórendszer állapota, vallási előírások, kulturális szokások, egészségkép, hiedelmek. Ez megegyezik egy német és holland kutatócsoport álláspontjával, amely szintén fontosnak tartja az orvostanhallgatók interkulturális képzésébe beépíteni az epidemiológiai szempontokat is. Közleményükben az alábbi 4 fó témát javasolják a képzésbe integrálni: „epidemiológia: a betegségek epidemiológiájának és terápiákra adott reakcióinak etnikai variációi”; „kultúra, etnicitás és identitás”; „szociális, gazdasági és 
jogi aspektusok”; valamint „kommunikáció” [26]. Végül, de nem utolsósorban, az interkulturális ismeretek tárgykörének fontos részét kell, hogy képezzék a többségi társadalomtól eltérő kulturális háttérrel rendelkező etnikai kisebbségek egészségével és egészségügyi ellátásával kapcsolatos speciális ismeretek, különös tekintettel arra a tényre, hogy hazánkban a roma etnikai kisebbség születéskor várható átlagos élettartama 10-15 évvel elmarad a nem roma emberekétől, és ennek hátterében fóként szociokulturális és életmódbeli tényezők állnak $[27,28]$. Ezen háttérismeretek nélkül nehéz interkulturálisan kompetens ellátásról beszélni, ezért fontos ezen ismereteket lehetőség szerint az orvosképzésbe és más egészségügyi dolgozók képzésébe beépíteni.

Az interkulturális kompetencia 'attitüd' komponensének felmérésére az idézett pécsi kutatás az alábbi részterületekre vonatkozóan tett fel kérdéseket. Elsőként egyes, egészségegyenlőtlenségekhez vezető tényezők szerepét értékelték a résztvevők 5 fokozatú Likert-skálán (például életmód, környezet, szegénység, iskolázottság, rasszizmus). Három kérdés vizsgálta a válaszadók önismeretét, tudatosságát ('awareness') a saját etnikai, kulturális identitásukra, esetleges sztereotípiáikra és előítéleteikre vonatkozóan, és összesen hat kérdés vonatkozott a munkavégzés során a szociokulturális tényezők szerepének, valamint a kulturáliskompetencia-képzés fontosságának értékelésére. Hasonlóképpen, számos más szerző is az interkulturális kompetencia 'attitüd' komponensének fogalomkörében értelmezi az egészségegyenlőtlenségekhez vezető tényezők (így például a szociokulturális háttér) kritikai értékelését, a saját kulturális háttérre való önreflexió képességét, kiegészítve a más kultúrák iránti érzékenységgel, nyitottsággal és a kulturális különbségek iránti tisztelettel [20]. Seeleman és mtsai szintén az 'attitűdök' komponens alatt értékeli annak felismerését és elfogadását, hogy a kultúra milyen hatással van az egyének viselkedésére és gondolkodására [19]. Az idézett hazai kutatás és annak előzményei az interkulturális kompetencia 'készség' komponensének tartalmát illetően a 2. táblázatban felsorolt készségeket tartják fontosnak klinikai környezetben, így az orvosképzés során ezen készségek fejlesztésére is érdemes törekedni és a hallgatók számára lehetőséget biztosítani ezek gyakorlására [4, 22, 23-25].

Like egészségügyi dolgozók klinikai kulturális kompetenciájának felmérésére irányuló kérdőívében egy külön szekció vizsgálja a válaszadók 'komfortérzetét szociokulturális felkészültséget igénylő helyzetekben' (3. táblázat) [22]. Más kutatások viszont a táblázatban részletezett helyzetekre való felkészültséget általában a 'készségek' ('skills') komponenshez sorolják [19, 21]. A két megközelítés között alapvetően nincs ellentmondás, inkább csak a kérdések fókuszában van az eltérés: Like kérdőíve a válaszadó által értékelt komfortérzetre fókuszál a munkavégzése során, melynek alacsony szintje adódhat például egyéni készségek vagy célzott képzésen való részvétel, felkészítés hiányából, és éppen ebben van a kulcs, hogy a komfortérzet a készségek fejlesztésével
2. táblázat Az interkulturális kompetencia 'készségek' komponensének egyes témakörei

Készségek önértékelése az alábbi témakörökben

Betegek fogadása, üdvözlése kulturálisan megfelelő módon (például kézfogás mely kultúrákban elfogadott, stb.)

Kideríteni a páciens nézőpontját az egészség/betegség vonatkozásában (például etiológia, kezelés, lefolyás, prognózis stb.)

Feltárni a páciens által alkalmazott népi vagy más alternatív gyógymódokat

Feltárni, hogy a páciens bevont-e a gyógyításába népi vagy más alternatív gyógyító személyeket

Kulturálisan megfelelő (szenzitív) fizikális vizsgálat

Kulturálisan megfelelő (szenzitív) kezelési terv előírása, megbeszélése Kulturálisan megfelelő (szenzitív) betegtájékoztatás és tanácsadás végzése

Kulturálisan megfelelő (szenzitív) prevenciós szolgáltatások nyújtása (oltás, szürés stb.)

Kulturálisan megfelelő (szenzitív) életvégi ellátás nyújtása

A páciens aktív egészségismeretének, egészségértésének (health literacy) felmérése (például mennyire érti meg a kezelési tervet) Együttmúködés orvosi, egészségügyi tolmácsokkal

A diagnózissal, kezeléssel kapcsolatos kultúrközi konfliktusokkal való megküzdés

Megküzdés a kultúraközi problémákkal a beteg együttmúködésének (compliance) és az utasítások pontos betartásának területén

Megküzdés a kultúraközi etikai konfliktusokkal, ellentétekkel

Elnézést kérni a kultúrák különbözőségéből adódó félreértések, hibák miatt

Forrás: saját szerkesztés $R$. C. Like klinikai kulturális kompetencia kérdöíve alapján adaptálva [22]

javítható. A készségek közül kiemelendő az interkulturális kommunikációs készség (beleértve a nem verbális kommunikációs jelek felismerésének és értelmezésének készségét és a tolmácsokkal való együttmúködés készségét stb.); továbbá a multikulturális környezetben és munkatársakkal való munkavégzés képessége és a derogáló, diszkriminatív megjegyzésekkel való megküzdési készségek is.

\section{Az interkulturálisan kompetens egészségügyi ellátás szintjei}

\section{Rendszer-és szervezeti szintü interkulturális kompetenciák}

$\mathrm{Az}$ interkulturális kompetencia fentiekben részletezett összetevői alapvetően az egyéni ismeretekre, tudatosságra, attitűdökre és készségekre vonatkoztak. Ha valódi, átfogó, interkulturálisan kompetens egészségügyi ellátásról beszélünk, az túl kell, hogy mutasson az egyéni kompetenciákon, és ki kell, hogy terjedjen szakmai, szervezeti és rendszerszintű kompetenciákra is: szándékra és célokra és az azok megvalósulását elősegítő tevékenységekre (például rendeletek, útmutatók, az egyes célokhoz rendelt források, képzések, monitorozás). 
3. táblázat $\mid$ Komfortérzet egyes, szociokulturális felkészültséget kívánó helyzetekben

Komfortérzet önértékelése az alábbi kultúrközi helyzetekben

Kulturálisan eltérő hátterű betegek ellátása

Magyarul nem vagy nem jól beszélő betegek ellátása

Ha olyan betegeket kell ellátnia, akik ragaszkodnak a népi vagy alternatív gyógyítók bevonásához a kezelésbe

Ha olyan hiedelmeket vesz észre, amelyek a beteg által nem kimondottak, de akadályozhatják a kezelési terv sikerességét

Ha olyan nem verbális kommunikációs jeleket vesz észre, amelyeknek eltérő jelentésük lehet a különböző kultúrákban

A fájdalom, aggódás, szenvedés kultúránként eltéró megnyilvánulásainak észlelése, értelmezése

Ha olyan tanácsot kell adni a betegnek az egészségromboló magatartásának megváltoztatására, amely az ő kulturális hiedelmeivel van összefüggésben

Ha indirekt módon kell a beteggel beszélnie a betegségéról, mivel esetében ez a kulturálisan megfelelő

Ha először a beteg családjával kell közölnie a „rossz híreket”, és nem a beteggel, mivel esetében ez a kulturálisan megfelelő

Kulturálisan eltérő hátterű egészségügyi dolgozókkal való munka, együttmúködés

Olyan kollégával együtt dolgozni, aki derogáló megjegyzést tesz eltérő kulturális háttterű páciensekre

Olyan pácienst kezelni, aki derogáló megjegyzést tesz az Ön eltérő kulturális háttterére

Olyan páciensekkel foglalkozni, akik derogáló megjegyzést tesznek más páciensek eltérő kulturális hátterére

A beteget kísérő vagy látogató nagyszámú családtaggal való foglalkozás

Olyan páciensekkel foglalkozni, akiknek kulturális okokból eltérô táplálkozási szokásaik vannak (például böjt, ramadán stb.)

Páciensek vallási szükségleteinek támogatása

Forrás: saját szerkesztés $R$. C. Like klinikai kulturális kompetencia kérdöíve alapján adaptálva [22]

Törvényi vagy rendeleti szinten Magyarországon nincs erre vonatkozó szabályozás, viszont a négy legnagyobb hazai egyetem orvostudományi karai által közösen jóváhagyott, az orvosi diplomához köthető általános kompetenciáknak fontos részét képezi a beteggel és a hozzátartozókkal való hatékony kommunikáció, beleértve többek között a tolmács segítségével történő kommunikációt is, amely egyben interkulturális kommunikációs készségeket is feltételez [29]. Bár a kompetencialistán nincs szó szerint megfogalmazva, hogy az orvos képes legyen 'interkulturálisan kompetens' ellátásokat nyújtani, az alkalmazott 'hatékony' kifejezés ezt magában foglalhatja (például rossz hírközlés, életvégi ellátás, kezelési terv megbeszélése esetén). Szervezeti szinten az interkulturálisan kompetens ellátás többnyire a vezetői szándék, motiváció és elkötelezettség, valamint a rendelkezésre álló források (pénzügyi és humánerőforrások stb.) függvénye.

Kórházak, egészségügyi szolgáltatók szintjén egy európai kezdeményezést, 'jó gyakorlatot' említenénk az interkulturális kompetencia szervezeti szintű megvalósu- lásának példájaként: 2003 és 2005 között zajlott egy, az Európai Unió által finanszírozott program, az ún. „migránsérzékeny kórház" projekt (migrant-friendly hospitals) [30]. A program nyolc európai klinikát foglalt magában, melyekben kísérleti jelleggel átfogó szervezeti fejlesztéseket és más beavatkozásokat hajtottak végre ('whole health system approach').

Fejlesztések és beavatkozások történtek például a következő területeken:

- a kórházi vezetés és menedzsment megnyerése és elköteleződése a cél érdekében;

- együttmúködések erősítése a helyi hatóságokkal, a szociális ellátórendszerrel és önkéntesekkel;

- tolmács és interkulturális mediátor szolgáltatások szervezése és elérhetôvé tétele az egészségügyi ellátórendszer számára;

- 'interkulturális kompetencia' képzések szervezése a klinika dolgozói számára;

- migránsok számára adaptált információs és edukációs anyagok és szolgáltatások fejlesztése;

- végül, de nem utolsósorban, fontos eleme volt a fejlesztéseknek a migránsközösségek bevonása a tervezés és a megvalósítás teljes folyamatába.

A projekt záródokumentuma, az ún. 'amszterdami nyilatkozat' ('Amsterdam Declaration') a két éven át tartó, intenzív fejlesztéseket magában foglaló program tapasztalatai alapján első európai ajánláscsomagként fogalmaz meg javaslatokat az EU tagállamai számára a bevándorlók, illetve a többségi társadalomtól eltérő etnokultúrájú populációk sajátos igényeinek kielégítése és a fogadó országok egészségügyi ellátórendszereinek fejlesztése érdekében $[30,31]$.

Felsőoktatási 'szervezeti' szinten az egyetemi vagy például (orvos)kari vezetés szándéka lehet a kar dolgozói és hallgatói interkulturális kompetenciáinak fejlesztése mind közvetlen, mind közvetett módokon. Ennek egy, az utóbbi években egyre nagyobb hangsúlyt kapott közvetett formája az ún. nemzetköziesítési törekvések vezetői támogatása, például hallgatói, oktatói mobilitások (például Erasmus) és kutatói együttmúködések ösztönzése, vendégoktatók fogadása, a külföldi hallgatói létszám növelése, nemzetközi rendezvények (például 'international evening') és más kezdeményezések támogatása [32]. A közelmúltból egy ilyen népszerü kezdeményezésnek tekinthető a Pécsi Tudományegyetemről (PTE) az '50 étel a nagyvilágból' címú különleges szakácskönyv kiadása, melyben az egyetem különböző karain tanuló magyar és külföldi hallgatók mutatják be egyegy népszerű hazai receptjüket [33]. Egy közvetlenebb, de szintén 'szervezeti szintü' módja lehet a dolgozók interkulturáliskompetencia-fejlesztésének az ún. oktatói készségfejlesztő workshopok szervezése. 2018 őszén került sor például a PTE Általános Orvostudományi Karán (ÁOK) egy ilyen rendezvényre „Kulturális sokféleség a PTE ÁOK oktatásában - az interkulturális kompetencia fejlesztésének lehetöségei” címmel, és a rendezvény rendkívül kedvező fogadtatásban és pozitív visszhangban része- 
sült a kari dolgozók részéről. A workshop során az ún. 'World Café' módszerrel, meghívott bikulturális vendégek bevonásával zajlott forgószínpad-szerüen az egyes kultúrkörökből származó hallgatói csoportokkal kapcsolatos kötetlen beszélgetés. A workshop eredményeképpen a részt vevő oktatók és adminisztratív dolgozók jobban megérthették az egy-egy kultúrkörhöz tartozó hallgatók magatartásának kulturális hátterét, valamint ötleteket kaphattak a hatékonyabb kommunikációhoz, a sikeresebb együttmúködéshez, és a rendezvény tapasztalatairól egy kari kiadvány is megjelent [34].

\section{Szakmai és egyéni szintü kompetenciák: interkulturáliskompetencia-képzések}

Bár szervezeti szintű támogatottságot igényel (akkreditáció, curriculumba építési szándék), mégis szakmai szintú kompetenciafejlesztési tevékenységnek tekinthetjük a PTE ÁOK képzési palettáján egyre szélesebb körben megjelenő, hallgatói interkulturális kompetenciák fejlesztését célzó választható kurzusok indítását, melyek magas látogatottsággal nagy népszerúségnek örvendenek a karon mind a magyar, mind a külföldi hallgatók körében.

Alapvetően két fó megközelítés ismert az interkulturáliskompetencia-képzési programokban. Az ún. kultúrákon átívelő (cross-cultural) megközelítés elsődlegesen a kommunikáció folyamatára és olyan közös kulturális és szociális tényezőkre fókuszál, amelyek több kultúrában is jelen vannak (például kirekesztettség, nemi szerepek, rasszizmus) [2]. Ilyen kurzusok például a hallgatók kisebbségek iránti érzékenyítését és toleranciaerősítését célzó „Interkulturális kommunikáció az orvostudományban” címü kurzus magyar és német nyelven a PTE ÁOK Magatartástudományi Intézetének gondozásában; továbbá az Egészségügyi Nyelvi és Kommunikációs Intézet által meghirdetett, az interkulturális kommunikációs készségeket és attitűdök fejlesztését célzó „Intercultural competence in doctor-patient communication" angol nyelvü kurzus, valamint 2019 óta a „Gyakorlati orvosi kommunikáció” címú elektív kurzus „A társadalmi és kulturális sokféleség kezelése az orvosi kommunikációban” modulja, magyar nyelven. A másik, hagyományosabb, ún. „kategorikus” megközelítés során az egyes kulturális csoportokkal kapcsolatos ismereteket, hiedelmeket és magatartásformákat tanítanak a résztvevőknek, és ennél a módszernél különösen fontos, hogy az egyes kultúrkörök, etnikai csoportok tárgyalása során kerüljük a sztereotipizálást. Ilyen jellegü kurzusok a 2019 óta elérhető „A roma, a hajléktalan, a menekült és a szexmunkás: a legsérülékenyebb társadalmi csoportok egészségproblémái és egészségügyi ellátásuk kihivásai” elnevezésú választható kurzus magyar és angol nyelven, és 2020 tavaszán, szintén két nyelven indult a „Migránsok és etnikai kisebbségek ellátása az EU-ban: egészségföldrajzi és interkulturális aspektusok" kurzus, mindkettő a PTE ÁOK Múveleti Medicina Tanszékének gondozásában. Ez utóbbi két kurzus kifejezetten a többségi társadalomtól eltérő szociokultu- rális hátterü populációk kulturálisan érzékeny ellátásával kapcsolatos ismeretekkel, készségekkel hivatott a hallgatókat, a jövő orvosait felvértezni, valamint fejleszteni az egyéni szintű interkulturális kompetenciáikat. Ezen kurzusok kifejlesztését előzte meg mintegy 'szükségletfelmérésként' a korábban említett, klinikai interkulturáliskompetencia-felmérés több mint 1200 medikushallgató bevonásával. A felmérés első részeredményeit 2019-ben publikáltuk, és a kurzusok fejlesztése és szervezése során igyekeztünk a hallgatói ötleteket, javaslatokat lehetőség szerint minél jobban figyelembe venni (például hiteles vendégoktatók felkérése, limitált csoportlétszám, változatos, interaktív és gyakorlati, szituatív pedagógiai módszerek alkalmazása, lehetőség biztosítása kötetlen vitákra, véleményütköztetésre, felkészülni az esetleges konfliktusok moderálására és mérsékelt, változatos számonkérési formák alkalmazása) [23]. A kutatás során számos specifikus, fejlesztendő területet is azonosítottunk, mint például a kulturálisan szenzitív életvégi ellátást, valamint a munkatársak, páciensek derogáló megjegyzéseivel szembeni megküzdést; ez utóbbi témában a PTE ÁOK Magatartástudományi Intézetének munkatársai kínálnak választható kurzusokat, illetve szükség esetén mentálhigiénés szolgáltatásokat.

Betancourt és mtsai az interkulturáliskompetencia-képzés „legjobb megközelítéseként” a kultúrközi ismeretek és kommunikációs készségek egyensúlyban való oktatását ajánlják, továbbá hangsúlyozzák a betegek szociokulturális hátterének jelentőségét és hatását az orvos-kliens interakciókra, döntéshozatalra és ezeken keresztül a kliens egészségi mutatóira [2]. A Pécsi Tudományegyetem kínálatában a fentiekben említett választható kurzusok egymással szinergiában és összhangban Betancourt 'legjobb megközelítésével' lehetőséget nyújtanak a hallgatók számára, hogy mind a hagyományos, 'kategorikus', mind pedig a 'kultúrákon átívelő' megközelítésből fejleszthessék egyéni interkulturális kompetenciáikat. Annak ellenére, hogy nehézséget jelenthet egy-egy új kurzus alapképzésbe illesztése a hallgatók túlterheltsége és időhiánya miatt, biztató, hogy a felmérés résztvevői fontosnak tartják az interkulturális kompetencia fejlesztésére irányuló képzési modulok (például választható kurzusok, $\mathrm{PhD}$ - és orvostovábbképző kurzusok) indítását a bevándorlás aktualitása miatt, valamint a saját interkulturális ismereteik, készségeik fejlődésének érdekében [23].

\section{Az interkulturálisan kompetens egészségügyi ellátás jelentősége, előnyei}

A releváns tudományos szakirodalom jelentős része hangsúlyozza a klinikai interkulturáliskompetencia-tartalmak orvosképzésbe integrálásának fontosságát, és számos közlemény a kulturáliskompetencia-képzési programok pozitív hatásairól számol be a kutatásban részt vevő medikusok, orvosok és egészségügyi dolgozók klinikai interkulturális ismeretei és készségei tekintetében [23- 
$25,30,35,36]$, illetve a betegelégedettség vonatkozásában $[5,35,36]$.

Bár egyelőre tudományosan nem igazolták, számos elismert szerző és kutatócsoport valószínúsíti, hogy az egészségügyi dolgozók fejlődő klinikai interkulturális kompetenciái közvetve pozitív hatással bírnak a betegek egészségi mutatóira is $[35,36]$. Ma már köztudott, hogy az egészségegyenlőtlenségekhez vezető okok multifaktoriálisak, és a legnagyobb mértékben olyan tényezők járulnak hozzá, amelyek az egészség társadalmi meghatározóival ('social determinants of health', SDH) kapcsolatosak $[37,38]$. Ilyen tényezók például az alacsony iskolai végzettség és foglalkoztatás, a biztosítás hiánya és az egészségügyi szolgáltatásokhoz való rosszabb hozzáférés is; tanulmányok igazolják, hogy a nyugati társadalmakban ezek az egyenlőtlenségek különösen nyilvánvalóak bizonyos etnikai és kulturális kisebbségek körében, legyen az hazai kisebbség vagy bevándorló populáció. Ez utóbbi csoportban különösképpen veszélyeztettnek tekinthetők a háborúk, illetve politikai, faji, vallási üldöztetés elől menekülő menedékkérők és a nemzetközi védelemben részesülők $[9,24,39,40]$. Az ellátás minőségére a társadalmi meghatározókon túl számos más tényező is hatással lehet, például az ellátórendszer és a beteg közötti kommunikáció, beleértve a döntéshozatali folyamatot is. Ugyanis az orvos-beteg kommunikáció során megjelennek vagy megjelenhetnek a betegek változatos elképzelései vagy hiedelmei a betegségük eredetével, okaival és lefolyásával kapcsolatosan, illetve a kezeléssel és a gyógyulással kapcsolatos elvárásaik és preferenciáik. Ezeket a tényezőket pedig erősen befolyásolja a kulturális háttér, ahogy a betegek orvoshoz fordulási szokásait is. Mindehhez még hozzájárul a betegek egészségmüveltsége és egészségértése, a kezelési terv és az orvosi utasítások megértésének és betartásának képessége ('health literacy') is, amelyeknek szintén lehet szociokulturális meghatározottságuk [38]. A klinikai interkulturáliskompetencia-képzési programok célja mindezzel összhangban, hogy specifikus ismeretekkel, készségekkel és eszközökkel vértezze fel az egészségügyi dolgozókat ahhoz, hogy jobban megértsék és kezelni tudják az egészséggel kapcsolatos hiedelmeket, értékeket és változatos magatartásformákat a kulturálisan, illetve etnikailag sokszínú populációk ellátása során. A képzések révén fejlődhet a résztvevők kulturális tudatossága, felismerhetik és megtanulhatják kezelni esetleges meglévő elöítéleteiket és sztereotípiáikat, hogy hatékonyan meg tudják előzni az ellátás során esetleg előforduló diszkriminatív megnyilvánulásokat, amelyek szintén egészségegyenlőtlenségekhez vezethetnek [27]. Kutatások igazolják, hogy az orvos és a beteg közötti kommunikáció közvetlenül kapcsolódik a beteg elégedettségéhez, ami pedig hatással lehet az orvossal való együttmúködésre (compliance), a megelőzést célzó intézkedések és az orvos utasításainak betartására (például szűrésen való részvétel, gyógyszerszedés), és ezáltal, közvetve, hozzájárulhat az ellátás minőségéhez, illetve a betegek egészségéhez $[2,41]$.

\section{Következtetés}

A klinikai interkulturáliskompetencia-képzések igazoltan javítják az egészségügyi dolgozók ismereteit, attitűdjeit és készségeit a multikulturális környezetben való betegellátással kapcsolatosan, és hozzájárulnak a hatékonyabb orvos-beteg kommunikáció megvalósulásához, ezáltal fokozzák az ellátásban részesülők elégedettségét és együttmúködését. Bár jelen ismereteink szerint ezen képzések pozitív hatása a betegek egészségére közvetlenül még nem bizonyítható, a fentiek alapján erősen valószínúsíthető, ezért az orvosok és egészségügyi dolgozók képzésébe integrálása javasolt $[5,23,35,36,41,42]$.

Anyagi támogatás: A kutatás a Magyar Tudományos Akadémia 'Bolyai János Kutatói Ösztöndíj’ támogatásával valósult meg. Az ösztöndíjas időszak: 2017/09/012020/08/31. Az Innovációs és Technológiai Minisztérium ÚNKP-19-4 kódszámú Új Nemzeti Kiválóság Programjának szakmai támogatásával készült. Támogatta a Pécsi Tudományegyetem Általános Orvostudományi Kar Kutatási Alap (PTE ÁOK-KA, nr. 2017-16).

Szerzői munkamegosztás: A tanulmány első változatát M. E. készítette, a közlemény végső formájának elkészítésében, szakmai és formai véleményezésében $\mathrm{N}$. T. nyújtott nélkülözhetetlen segítséget. A cikk végleges változatát mindkét szerző elolvasta és jóváhagyta.

Érdekeltségek: A szerzőknek nincsenek érdekeltségeik.

\section{Irodalom}

[1] World Health Organization, Regional Office for Europe. Stepping up action on refugee and migrant health. Towards a WHO European framework for collaborative action. Outcome document of the High-level Meeting on Refugee and Migrant Health, 23-24 November 2015, Rome, Italy. Available from: http:// www.euro.who.int/_data/assets/pdf_file/0008/298196/ Stepping-up-action-on-refugee-migrant-health.pdf [accessed: April 5, 2020].

[2] Betancourt JR, Green AR, Garrillo JE, et al. Defining cultural competence: a practical framework for addressing racial/ethnic disparities in health and health care. Public Health Rep. 2003; 118: 293-302.

[3] Rechel B, Mladovsky P, Ingleby D, et al. Migration and health in an increasingly diverse Europe. Lancet 2013; 381: 1235-1245.

[4] Like RC. Educating clinicians about cultural competence and disparities in health and health care. J Contin Educ Health Prof. 2011; 31: 196-206.

[5] Kagawa-Singer M, Kassim-Lakha S. A strategy to reduce crosscultural miscommunication and increase the likelihood of improving health outcomes. Acad Med. 2003; 78: 577-587.

[6] UNESCO Universal Declaration on Cultural Diversity. [UNESCO Egyetemes Nyilatkozat a Kulturális Sokszínűségről.] Available from: http://www.unesco.org/new/fileadmin/ MULTIMEDIA/HQ/CLT/diversity/pdf/declaration_cultural_diversity_hu.pdf [accessed: April 5, 2020]. [Hungarian]

[7] Hofstede G. Cultures and organizations: software of the mind. 2nd edition. McGraw-Hill, New York, NY, 2005.

[8] Weaver GR. Understanding and coping with cross-cultural adjustment stress. In: Weaver GR. (ed.) Culture, communication 
and conflict: readings in intercultural relations. 2nd edition. Mass, Simon and Schuster Publishing, Needham Heights, MA 1998; pp. 187-204

[9] Helman CG. Culture, health and illness. Fifth edition. CRC Press, London, 2007.

[10] Hofstede G. Dimensionalizing cultures: the Hofstede model in context. Online Readings Psychol Cult. 2011;2: 8.

[11] Baráth Á. Cultural competence and social work. [Kulturális kompetencia és szociális munka.] Esély 2019; 30(2): 110-128. [Hungarian]

[12] Landy D. (ed.) Culture, disease, and healing: studies in medical anthropology. Macmillan, New York, NY, 1977.

[13] Koehn PH, Swick HM. Medical education for a changing world: moving beyond cultural competence into transnational competence. Acad Med. 2006; 81: 548-556.

[14] Renschler I, Cattacin S. Comprehensive 'Difference Sensitivity' in health systems. In: Björngren-Cuadra C, Cattacin S. (eds.) Migration and health: difference sensitivity from an organisational perspective. IMER, Malmö, 2007; pp. 37-41.

[15] Cross T, Bazron B, Dennis K, et al. Towards a culturally competent system of care. Georgetown University Child Development Center, CASSP Technical Assistance Center, Washington, DC, 1989.

[16] Betancourt J, Green A, Carrillo J. Cultural competence in health care: emerging frameworks and practical approaches. Field report. The Commonwealth Fund, New York, NY, 2002.

[17] Byram M. Intercultural competence in foreign languages - the intercultural speaker and the pedagogy of foreign language education. In: Deardorff DK. (ed.) The SAGE Handbook of Intercultural Competence. Thousand Oaks, San Francisco, CA, 2009 pp: $321-332$.

[18] Walinski J. Enhancing intercultural communicative competence in an online collaborative assessment environment: CEFcult project (2012). In: Pezik P (ed.) Corpus data across languages and disciplines. Peter Lang Publishing, Frankfurt am Main, 2012; pp. 55-65.

[19] Seeleman C, Suurmond J, Stronks K. Cultural competence: a conceptual framework for teaching and learning. Med Educ. 2009; 43: 229-237

[20] Watt K, Abbott P, Reath J. Developing cultural competence in general practitioners: an integrative review of the literature. BMC Fam Pract. 2016; 17: 158

[21] Papadopoulos I. The Papadopoulos, Tilki and Taylor model of developing cultural competence. In: Papadopoulos I. (ed.) Transcultural health and social care: Development of culturally competent practitioners. Churchill Livingstone Elsevier, Edinburgh, 2006; pp. 7-24.

[22] Like RC. Clinical cultural competency questionnaire (pre-training version). Center for Healthy Families and Cultural Diversity, Department of Family Medicine, UMDNJ - Robert Wood Johnson Medical School, 2001. Available from: http://rwjms.umdnj.edu/departments_institutes/family_medicine/chfcd/grants projects/documents/Pretraining.pdf [accessed: April 5, 2020].

[23] Marek E, Schmél D, Katz, Z, et al. Interculturality and healthcare provision. [Gyógyítás és interkulturalitás.] Egészségfejlesztés 2019; 60(4): 30-45. [Hungarian]

[24] Ladson GM, Lin JM, Flores A, et al. An assessment of cultural competence of first-and second-year medical students at a historically diverse medical school. Am J Obstet Gynecol. 2006; 195: 1457-1462.

[25] Okoro ON, Odedina FT, Reams RR, et al. Clinical cultural competency and knowledge of health disparities among pharmacy students. Am J Pharm Educ. 2012; 76: 40 .

[26] Knipper M, Seeleman IC, Essink ML. How should ethnic diversity be represented in medical curricula? A plea for systematic training in cultural competence. Tijdschrift voor Medisch Onderwijs 2010; 29: 54-60.

[27] European Comission 2014: Roma health report. Health status of the Roma population. Data collection in the member states of the European Union. Available from: https://ec.europa.eu/ health/sites/health/files/social_determinants/docs/2014_ roma_health_report_en.pdf [accessed: April 5, 2020].

[28] Szirtesi Z. Health status of the Roma. [A cigányság egészségügyi helyzete.] Agroinform Kiadó, Budapest, 1998. [Hungarian]

[29] Competencies attached to a medical diploma. [Orvosi diplomához köthető kompetenciák.] 2012. Available from: https:// aok.pte.hu/docs/th/file/2012/Kompetencialista2012.pdf [accessed: April 5, 2020]. [Hungarian]

[30] Krajic K, Stramayr C, Karl-Trummer U, et al. Improving ethnocultural competence of hospital staff by training: experiences from the European "migrant-friendly hospitals" project. Divers Health Social Care 2005; 2: 279-290.

[31] The Amsterdam Declaration. Towards migrant-friendly hospitals in an ethno-culturally diverse Europe. In: "Hospitals in a culturally diverse Europe". International conference on quality-assured health care and health promotion for migrants and ethnic minorities. European Commission, Amsterdam, 2004. Available from: http://ec.europa.eu/health/ph_projects/2002/promotion/fp_promotion_2002_annex7_14_en.pdf [accessed: April 5, 2020].

[32] Németh T. The intercultural impact of the Erasmus programme on Hungarian students, with special regard to students of medicine and health care (PhD thesis). Faculty of Sciences, University of Pécs, 2015.

[33] P. Horváth T, Berta A. (eds.) 50 delicacies on Earth. [50 étel a nagyvilágból.] Pécsi Tudományegyetem, Kapcsolati és Nemzetköziesítési Igazgatóság, Pécs, 2019. [Hungarian]

[34] Faubl N, Füzesi Zs., Németh T. (eds.) Cultural diversity in the training program of the PTE AOK. Opportunities for the development of intercultural competence. Lessons from a workshop. [Kulturális sokféleség a PTE ÁOK oktatásában. Az interkulturális kompetencia fejlesztésének lehetőségei. Egy workshop tanulságai.] Pécsi Tudományegyetem, Általános Orvostudományi Kar, Magatartástudományi Intézet, Orvosi Oktatásfejlesztési és Kommunikációs Tanszék, Pécs, 2018. Available from: https://aok. pte.hu/docs/magtud/file/Kulturalis_sokfeleseg_a_PTE_AOK_ oktatasaban.pdf. [Hungarian]

[35] Beach MC, Price EG, Gary TL, et al. Cultural competency: a systematic review of health care provider educational interventions. Med Care 2005; 43: 356-373.

[36] Betancourt JR, Green AR. Commentary: linking cultural competence training to improved health outcomes: perspectives from the field. Acad Med. 2010; 85: 583-585.

[37] Wilkinson RG, Marmot M. (eds.) Social determinants of health: the solid facts. WHO Regional Office for Europe, Copenhagen, 1998.

[38] Marmot M, Allen J, Goldblatt P, et al. Fair Society, Healthy Lives - The Marmot Review: Strategic review of health inequalities in England post-2010. Available from: https://www.parliament. uk/documents/fair-society-healthy-lives-full-report.pdf [accessed: April 5, 2020].

[39] Davies AA, Basten A, Frattini C. Migration: a social determinant of migrants' health. Eurohealth 2010; 16: 10-12.

[40] Ingleby D. Ethnicity, Migration and the 'Social Determinants of Health' Agenda. Psychosoc Interv. 2012; 21: 331-341.

[41] Kleinman A, Eisenberg L, Good B. Culture, illness, and care: clinical lessons from anthropologic and cross-cultural research. Ann Intern Med. 1978; 88: 251-258. Focus 2006; 88: 251-258.

[42] Seeleman C, Hermans J, Lamkaddem M, et al. A students' survey of cultural competence as a basis for identifying gaps in the medical curriculum. BMC Med Educ. 2014; 14: 216.

(Marek Erika dr., Pécs, Szigeti út 12., 7627 e-mail: erika.marek@aok.pte.hu)

A cikk a Creative Commons Attribution 4.0 International License (https://creativecommons.org/licenses/by/4.0/) feltételei szerint publikált Open Access közlemény. (SID_1) 